\title{
Morphological and cytoenzymatic characterization of haemocytes of the venus clam Chamelea gallina
}

\author{
Daniela M. Pampanin*, M. Gabriella Marin, Loriano Ballarin \\ Department of Biology, University of Padova, Via U. Bassi 58/B, 35121 Padova, Italy
}

\begin{abstract}
A morphological and enzymatic characterization of Chamelea gallina haemocytes was carried out as a prerequisite for further studies on venus clam immunobiology. Two main types of circulating haemocytes were identified (1) hyalinocytes (79.2\%), agranular cells with a central nucleus surrounded by a little cytoplasm, and (2) granulocytes $(16.5 \%)$, smaller granular cells with smaller nuclei. Small cells with a strongly basophilic nucleus and a thin layer of peripheral cytoplasm, probably undifferentiated blast cells (4.3\%), were also observed. Both granulocytes and hyalinocytes can assume a spreading or round morphology. The enzymatic activities of haemocytes were also investigated. Some of the granulocytes and hyalinocytes were positive for hydrolytic enzymes, suggesting a role for these cells in phagocytosis; no oxidative enzymes were detected in C. gallina haemocytes. Granulocytes and hyalinocytes can easily adhere to the substratum and exhibit a low phagocytosis activity towards foreign particles $(6.3 \%)$, whereas the fraction of cells containing ingested material significantly increased after pre-incubation of test particles with cell-free haemolymph, which suggests the presence of opsonin(s) in the haemolymph.
\end{abstract}

KEY WORDS: Haemocytes · Chamelea gallina $\cdot$ Cytoenzymology $\cdot$ Phagocytosis Resale or republication not permitted without written consent of the publisher

\section{INTRODUCTION}

Venerid clams represent an important economic resource throughout the world. In Italy, major fisheries are located along the central and northern Adriatic coastlines, and Chamelea gallina is by far the most exploited species, with peaks of total catch (using hydraulic dredges) of more than $100000 \mathrm{t} \mathrm{yr}^{-1}$ in the 1980s (Froglia 1989, Del Piero 1998). C. gallina is a common infaunal filter-feeding organism in the Mediterranean Sea, living in habitats characterized by limited variations in temperature and salinity. Intense fishing efforts on this economically relevant species (Froglia 1975,1989, Barillari et al. 1978, del Piero 1998) have compromised the natural resource because of the higher risk of mortality in populations stressed by overfishing. C. gallina fisheries experienced significant mortalities in 1991, 1993, 1996, 1998.

*E-mail: pampanin@ibm.ve.cnr.it
One effect of stress may be the suppression of immune responses, making the clams more vulnerable towards invading organisms. Haemocytes play an important role in mollusc immunity, as they are involved in the recognition of invading foreign organisms and their subsequent ingestion, encapsulation or lysis (Adema et al. 1991, Vetvicka and Sima 1998). Lytic enzymes play a key role in these processes. They are produced in the granulocytes and released into phagosomes (Cheng \& Cali 1974, Cheng \& Rodrick 1975, Cheng 1983, Yoshino 1988, Pipe 1990, Pipe et al. 1995, Cajaraville et al. 1996, Carballal et al. 1997c). Lysosomal hydrolases are compartmentalized within electron-dense specific granules (Yoshino \& Cheng 1976, Rodrick \& Ulrich 1984, Pipe 1990). Degranulation has been associated with the release of lysosomal enzymes into serum during active phagocytosis (Cheng 1981, Mohandas et al. 1985, Cheng \& Dougherty 1989).

Most studies on bivalve haemocytes have been carried out on oysters and mussels, and few studies have investigated species belonging to the Veneridae 
(Cheney 1971, Foley \& Cheng 1974, Moore \& Eble 1977, Huffman \& Tripp 1982, Lopez et al. 1997a,b). Since no data are available concerning Chamelea gallina haemocytes and their role in immunity, we carried out a morpho-functional characterization of C. gallina haemocytes as a prerequisite for further studies on the immunobiology of the venus clam in order to define a series of immuno-biomarkers to be used in the evaluation of stress conditions for this species.

Our results indicate the presence of 2 main haemocyte types, namely granulocytes and hyalinocytes, both exhibiting lysosomal enzymes and phagocytosis activity.

\section{MATERIALS AND METHODS}

Clams (shell length 20 to $30 \mathrm{~mm}$ ) were collected with a hydraulic dredge at Venice Lido, on the west coast of the Northern Adriatic Sea, in front of the Venice lagoon. They were kept in the laboratory for 2 to $3 \mathrm{~d}$ before experiments in $70 \mathrm{l}$ tanks filled with aerated seawater that was renewed every other day (salinity $35 \pm 1 \%$; temperature $17 \pm 1^{\circ} \mathrm{C}$ ) and fed with microalgae (Isochrysis galbana and Phaeodactylum tricornutum).

Heamolymph collection. Haemolymph was collected from the anterior adductor muscle of clams with a syringe containing $10 \mathrm{mM}$ of L-cysteine in filtered seawater (FSW), $\mathrm{pH} 7.5$, to a final dilution of $1: 1$ haemolymph/L-cysteine. Haemolymph was also collected in the absence of L-cysteine and centrifuged at $780 \times g$ for $10 \mathrm{~min}$ to pellet cells and obtain cell-free haemolymph $(\mathrm{CFH})$.

Haemocyte cultures. Haemolymph was centrifuged at $780 \times g$ for $10 \mathrm{~min}$ and the pellet was resuspended in FSW to achieve a final concentration of $10^{6}$ cells $\mathrm{ml}^{-1}$. Sixty $\mu$ l of haemocyte suspension were placed in the centre of a culture chamber, which was fitted with coverslips and incubated for $30 \mathrm{~min}$ at room temperature to allow the cells to adhere to the coverslips.

Haemocyte morphology. Haemocyte monolayers were fixed for $30 \mathrm{~min}$ at $4^{\circ} \mathrm{C}$ in a solution of $1 \%$ glutaraldehyde in FSW containing $1 \%$ saccharose. They were then washed in phosphate-buffered solution (PBS: $1.37 \mathrm{M} \mathrm{NaCl}$; $0.03 \mathrm{M} \mathrm{KCl} ; 0.015 \mathrm{M} \mathrm{KH}_{2} \mathrm{PO}_{4}$;

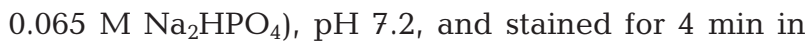
$10 \%$ Giemsa solution. Finally, haemocytes were mounted in Acquovitrex (Carlo Erba). Observation was carried out with a Leica DMLB light microscope at 1250×. Haemocytes were incubated in Neutral Red (Merck) solution (8 $\mathrm{mg} \mathrm{l}^{-1}$ in FSW) and observed immediately to identify lysosomal compartments.

Adhesion assay. The number of haemocytes in 30 fields were evaluated and compared with that of monolayers on poly-L-cysteine-treated coverslips to assess the adhesion index, i.e. the percentage of adhering cells on untreated coverslips. The haemocytes were stained with Giemsa, mounted and observed with image-analysis equipment (Casti Imaging).

Phagocytosis assay. Haemocyte monolayers were incubated for $60 \mathrm{~min}$ at room temperature with $60 \mu \mathrm{l}$ of either a yeast (Saccharomyces cerevisiae) suspension in FSW (yeast/hemocyte ratio $=10: 1$ ) or $1 \%$ carmine in FSW and incubated. Carmine was also pre-incubated for $30 \mathrm{~min}$ in $\mathrm{CFH}$ to examine opsonic activity. After incubation, uningested particles were washed out by dipping in FSW. Haemocytes were finally fixed, stained with Giemsa solution, mounted and observed under a light microscope. Attached foreign particles were enumerated.

Cytoenzymology. Haemolymph was collected in Alsever's solution (4.2 g NaCl; 8 gr sodium citrate; $0.55 \mathrm{~g}$ citric acid; 20.5 glucose), pH 7.5, and $300 \mu$ of haemocyte suspension $\left(10^{5}\right.$ cells ml $\left.{ }^{-1}\right)$ were spun at $18 \times g$ for 3 min (Cytospin 3, Shandon), air-dried for $20 \mathrm{~min}$ and fixed in glutaraldehyde. Specific cytochemical reactions were employed to demonstrate the presence of several hydrolytic and oxidative enzymes on haemocytes. Substrates were omitted from control slides. For $\beta$-glucuronidase and acid phophatase assays, cells were also pre-incubated for $60 \mathrm{~min}$ with $3 \mu \mathrm{m}$ latex beads.

Acid esterase (Lojda 1977): Haemocytes were washed with $0.1 \mathrm{M}$ phosphate-citric acid, $\mathrm{pH}$ 5.5, and incubated for $16 \mathrm{~h}$ at $4^{\circ} \mathrm{C}$ in the following reaction mixture: $3 \mathrm{mg}$ naphthol acetate (Sigma) dissolved in $500 \mu \mathrm{l}$ acetone, $250 \mu \mathrm{l}$ Solution A (0.4 g new fuchsin [Sigma], $2 \mathrm{ml}$ $\mathrm{HCl} 36 \%$, $8 \mathrm{ml}$ distilled water), $250 \mu \mathrm{l}$ Solution B (4\% $\mathrm{NaNO}_{2}$ in distilled water), and $19 \mathrm{ml}$ phosphate-citric acid buffer. Haemocytes were then washed with distilled water and mounted. Enzyme-reactive sites stained pink-brown.

Acid phosphatase (Lojda et al. 1979): Haemocytes were washed in $0.1 \mathrm{M}$ sodium acetate, $\mathrm{pH} 5.2$, for 10 min and incubated for $3 \mathrm{~h}$ at $37^{\circ} \mathrm{C}$ in a reaction mixture made by dissolving $10 \mathrm{mg}$ naphthol AS-B phosphate (Sigma) in $400 \mu \mathrm{l}$ dimethylformamide (DMF), $400 \mu \mathrm{l}$ Solution A, $400 \mu \mathrm{l}$ Solution B, and $20 \mathrm{ml}$ of sodium acetate buffer $(0.1 \mathrm{M}, \mathrm{pH}$ 5.2). After incubation, haemocytes were washed in the buffer solution and mounted. Enzyme-reactive sites stained red.

Alkaline phosphatase (Burstone 1962): Haemocytes were washed with $0.1 \mathrm{M}$ Tris- $\mathrm{HCl}, \mathrm{pH}$ 9, for $10 \mathrm{~min}$ and incubated for $2 \mathrm{~h}$ at $37^{\circ} \mathrm{C}$ in a reaction mixture similar to that used for acid phosphatase detection, but containing $20 \mathrm{ml}$ of Tris- $\mathrm{HCl}$ buffer instead of sodium acetate. Haemocytes were then washed for $10 \mathrm{~min}$ in Tris-HCl and mounted. Enzyme-reactive sites stained red. 
Arylsulphatase (Goldfisher 1965): Haemocytes were washed for $10 \mathrm{~min}$ in $0.1 \mathrm{M}$ sodium acetate, $\mathrm{pH}$ 5.2, and incubated for $2 \mathrm{~h}$ at $37^{\circ} \mathrm{C}$ in $0.16 \mathrm{~g}$ of $p$-nitrocatecholsulphate (Sigma) in $4 \mathrm{ml}$ distilled water, $12 \mathrm{ml}$ sodium acetate buffer, and $4 \mathrm{ml} 8 \% \mathrm{PbNO}_{3}$. After incubation, haemocytes were washed with distilled water and then with ammonium sulphide solution for 2 min. Finally, they were washed with distilled water and mounted. Enzyme-reactive sites stained brownish-black.

Chloroacetyl esterase (Moloney et al. 1960): Haemocytes were washed in PBS, pH 6.5, for 10 min and incubated for $1 \mathrm{~h}$ at room temperature in a reaction mixture made by dissolving $6 \mathrm{mg}$ naphtol chloroacetate (Sigma) in $1 \mathrm{ml}$ DMF, and finally added to $19 \mathrm{ml}$ PBS containing 20 mg Fast Blue B (Fluka). They were then washed in PBS and mounted. Enzyme-reactive sites stained blue.

B-glucuronidase (Hayashi et al. 1964): Haemocytes were washed in $0.1 \mathrm{M}$ sodium acetate, $\mathrm{pH} 5.2$, for $10 \mathrm{~min}$ and incubated for $3 \mathrm{~h}$ at $37^{\circ} \mathrm{C}$ in the following reaction mixture: $4 \mathrm{mg}$ naphtol AS-BI $\beta$-glucuronide (Sigma) dissolved in $250 \mu \mathrm{DMF}, 400 \mu$ l Solution A, $400 \mu \mathrm{l}$ Solution B and $20 \mathrm{ml}$ of sodium acetate buffer. After incubation, haemocytes were washed in sodium acetate buffer and mounted. Enzyme-reactive sites stained red.

Nonspecific esterase (Gomori 1948): Haemocytes were washed with PBS for $10 \mathrm{~min}$ and incubated for $3 \mathrm{~h}$ at $4{ }^{\circ} \mathrm{C}$ in the following reaction mixture: $10 \mathrm{mg}$ naphtol AS-D acetate (Sigma) dissolved in $1 \mathrm{ml}$ acetone, added to $49 \mathrm{ml}$ PBS containing $80 \mathrm{mg}$ Fast Blue B (Sigma). Haemocytes were then washed in PBS and mounted. Enzyme-reactive sites stained blue.

$5^{\prime}$-nucleotidase (Wachstein \& Meisel 1957): Haemocytes were washed for $10 \mathrm{~min}$ in $0.2 \mathrm{M}$ Tris-maleate, $\mathrm{pH} 7.2$, and incubated for $2 \mathrm{~h}$ at $37^{\circ} \mathrm{C}$ in $20 \mathrm{mg}$ adenosine-5'-monophosphate (AMP, Sigma) dissolved in $22 \mathrm{ml}$ of distilled water, $20 \mathrm{ml}$ Tris-maleate buffer and $3 \mathrm{ml}$ of $2 \%$ aqueous solution of $\mathrm{PbNO}_{3}$ containing $5 \mathrm{ml}$ $\mathrm{MgSO}_{4}$. Haemocytes were then washed with distilled water and immersed in 1\% ammonium sulphide solution for 2 min. Finally, they were washed with distilled water and mounted. Enzyme-reactive sites stained black.

Peroxidase (Graham \& Karnovsky 1966): Haemocytes were washed in PBS for $10 \mathrm{~min}$ and incubated for $2 \mathrm{~h}$ at $37^{\circ} \mathrm{C}$ in $0.5 \mathrm{mg} \mathrm{ml}^{-1}$ of $3-3^{\prime}$ diaminobenzidine tetrahydrochloride (DAB, Sigma) in distilled water containing $0.02 \% \mathrm{H}_{2} \mathrm{O}_{2}$. Then haemocytes were washed in distilled water and mounted. Enzyme-reactive sites stained brown.

Phenoloxidase (Hose et al. 1987): Haemocytes were washed with PBS for $10 \mathrm{~min}$ and incubated for $30 \mathrm{~min}$ at $37^{\circ} \mathrm{C}$ in a saturated solution of L-dihydroxyphenylL-alanine (L-DOPA). They were then washed with PBS and mounted. Enzyme-reactive sites stained black.

Statistical analysis. All experiments were repeated 4 times, using pools of haemolymph from 10 clams each. The percentage of positive haemocytes and the phagocytic index (percentage of phagocytic haemocytes) were evaluated on 1500 cells per pool. Statistical analysis of haematocrit values was performed using a Student's $t$-test.

\section{RESULTS}

Two main types of circulating haemocytes were identified: hyalinocytes and granulocytes. Hyalinocytes $(79.2 \%)$ were generally devoid of granulations and had a large, dark blue basophilic nucleus surrounded by light blue cytoplasm. Granulocytes $(16.5 \%)$ were smaller than hyalinocytes, with smaller, dark blue nuclei and blue-stained basophilic granules in their cytoplasm (Fig. 1B). Haemocytes with a strongly basophilic nucleus and a thin, light blue peripheral cytoplasm were also found $(4.3 \%)$; they probably represent blast cells or undifferentiated haemocytes (Fig. 1A). Both granulocytes and hyalinocytes can assume a spreading (irregular shape with pseudopodia of varying lengths) or a round morphology (Table 1). Among granulocytes, $81.1 \%$ were spreading cells, whereas $18.9 \%$ were round cells, and $53.2 \%$ of hyalinocytes were spreading cells and $46.8 \%$ were round cells (Fig. 1A). Table 2 shows the mean values of cell $(\mathrm{C})$ and nucleus (N) sizes (longest axis excluding pseudopodia and longest nuclear diameter, respectively), measured by image analysis, and the $\mathrm{N} / \mathrm{C}$ ratio. Hyalinocytes $(\mathrm{C}=11.51 \mu \mathrm{m}, \mathrm{N}=4.74 \mu \mathrm{m})$ were bigger than granulocytes $\left(\mathrm{C}=9.42 \mu \mathrm{m}_{i} \mathrm{~N}=4.48 \mu \mathrm{m}\right)$, but had a smaller N/C ratio. Blasts were the smallest cell type and had the highest N/C ratio. Spreading cell dimensions were more variable. A low number $(<1 \%)$ of binucleated circulating cells was also observed. A haematocrit value (concentration of circulating cells) of 1.2 to $2.4 \times 10^{6}$ cells $\mathrm{ml}^{-1}$, evaluated on pools of 10 clams, shows seasonal variations, which were significantly higher in spring and summer (Fig. 2).

Table 1. Chamelea gallina. Morphological characterization of haemocytes obtained on Giemsa-stained slides. Values are mean $( \pm \mathrm{SD}, \mathrm{n}=4)$ percentage of various cell types

\begin{tabular}{|ccc|}
\hline $\begin{array}{c}\text { \% granulocytes } \\
16.5 \pm 1.3\end{array}$ & $\begin{array}{c}\text { \% hyalinocytes } \\
79.2 \pm 1.3\end{array}$ & $\begin{array}{c}\text { \% blast cells } \\
4.3 \pm 1.1\end{array}$ \\
\hline $\begin{array}{c}\text { \% spreading } \% \text { round } \\
81.1 \pm 2.5\end{array} \quad \begin{array}{c}\text { \% spreading } \\
\text { 18.9 } \pm 2.5\end{array}$ & $53.2 \pm 2.6 \quad 46.8 \pm 2.6$ & \\
\hline
\end{tabular}


Table 2. Chamelea gallina. Mean $( \pm \mathrm{SD})$ nuclear and cell diameters and their ratio $(\mathrm{N} / \mathrm{C})$ in haemocytes. $\mathrm{n}=$ sample size

\begin{tabular}{|lcccrr|}
\hline Parameter & $\begin{array}{c}\text { Granulocytes } \\
(\mathrm{n}=100)\end{array}$ & $\begin{array}{c}\text { Hyalinocytes } \\
(\mathrm{n}=100)\end{array}$ & $\begin{array}{c}\text { Blast cells } \\
(\mathrm{n}=50)\end{array}$ & $\begin{array}{c}\text { Spreading cells } \\
(\mathrm{n}=100)\end{array}$ & $\begin{array}{c}\text { Round cells } \\
(\mathrm{n}=100)\end{array}$ \\
\hline Cell diam. $(\mu \mathrm{m})$ & $9.42 \pm 4.05$ & $11.51 \pm 3.92$ & $5.97 \pm 0.72$ & $10.73 \pm 4.27$ & $7.71 \pm 1.80$ \\
Nuclear diam. $(\mu \mathrm{m})$ & $4.48 \pm 0.73$ & $4.74 \pm 0.90$ & $4.26 \pm 0.55$ & $4.60 \pm 0.84$ & $3.86 \pm 0.64$ \\
N/C & $0.48 \pm 0.15$ & $0.41 \pm 0.10$ & $0.71 \pm 0.11$ & $0.43 \pm 0.12$ & $0.50 \pm 0.11$ \\
\hline
\end{tabular}

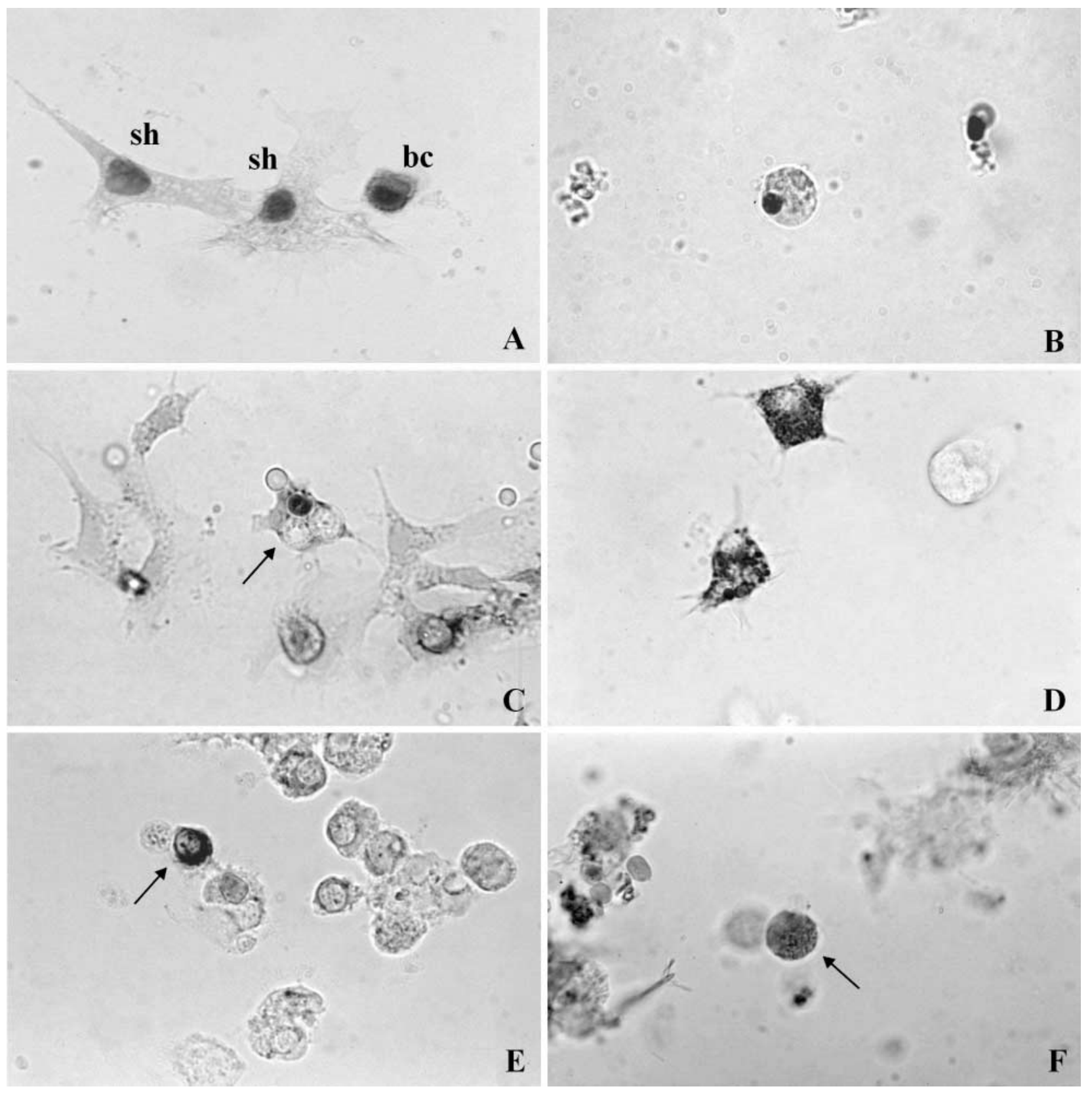

Fig. 1. Chamelea gallina haemocytes. (A) Spreading haemocytes (sh) and stem cell (sc) after Giemsa staining; (B) round granulocyte after Giemsa staining; (C) haemocyte containing 2 ingested yeast cells (arrowed); (D) cytoplasmic granules stained with Neutral Red dye; (E) haemocyte positive for $\beta$-glucuronidase activity (arrowed); (F) haemocyte positive for chloroacetyl esterase activity (arrowed). Light microscopy 1250x 


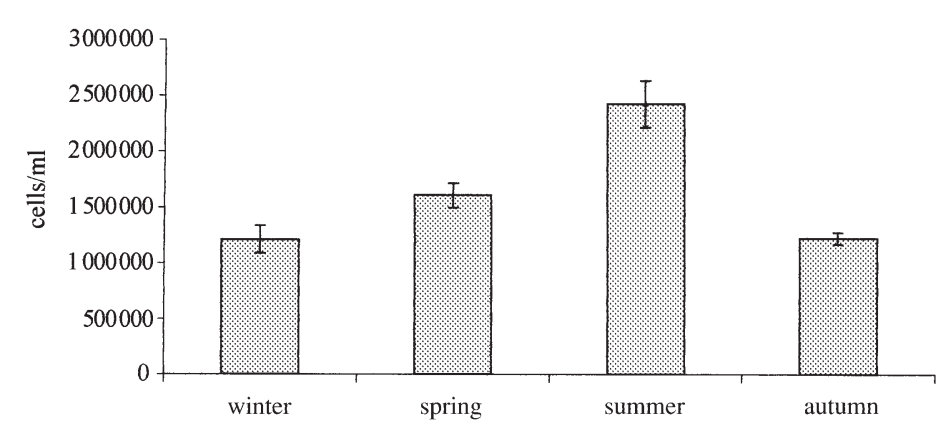

Fig. 2. Chamelea gallina. Seasonal variations in haematocrit values of hemolymph (mean $\pm \mathrm{SD}, \mathrm{n}=3$ )

A low percentage $(6.3 \pm 1.3 \%)$ of haemocytes were able to phagocytize yeast cells (Fig. 1C), whereas most of them $(92.7 \pm 5.4 \%)$ adhered to glass slides. The adhesion assay proved that all cell types adhere to, and spread on glass coverslips. In the phagocytic assay in the presence of carmine particles: $2.8 \%( \pm 1.01)$ of granulocytes and $9.8 \%( \pm 0.2)$ of hyalinocytes showed phagocytic ability. After pre-incubation with $\mathrm{CFH}_{\text {, }}$ these percentages increased (phagocytic granulocytes:

Table 3. Chamelea gallina. Enzymatic activity of haemocytes. Values are mean $( \pm \mathrm{SD}, \mathrm{n}=4)$ percentage of positive cells. -: no activity

\begin{tabular}{|lcc|}
\hline Enzimatic activity & $\begin{array}{c}\text { \% granulocytes } \\
\text { (mean } \pm \text { SD) }\end{array}$ & $\begin{array}{c}\% \text { hyalinocytes } \\
\text { (mean } \pm \text { SD) }\end{array}$ \\
\hline Hydrolase & & \\
Arylsulphatase & $25.3 \pm 3.1$ & $41.2 \pm 2.2$ \\
Chloroacetyl esterase & $27.9 \pm 1.2$ & $51.3 \pm 0.7$ \\
Acid esterase & - & - \\
Non-specific esterases & $36.4 \pm 2.5$ & $28.2 \pm 1.8$ \\
5'-nucleotidase & - & - \\
Acid phosphatase & $12.3 \pm 1.0$ & $25.6 \pm 0.6$ \\
Alkaline phosphatase & - & - \\
$\beta$-glucuronidase & $2.8 \pm 1.2$ & $3.6 \pm 0.5$ \\
Oxidase & - & - \\
Phenoloxidase & - & - \\
Peroxidase & & \\
\hline
\end{tabular}

Table 4. Chamelea gallina. Enzymatic activity of haemocytes. Values are mean $( \pm \mathrm{SD}, \mathrm{n}=4)$ percentage of positive granulocytes and hyalinocytes with and without pre-incubation with latex. Statistical comparison was performed by Student's $t$-test. ${ }^{* * *} \mathrm{p}<0.001$; ns: not significant at $\mathrm{p}>0.05$

\begin{tabular}{|c|c|c|c|c|}
\hline \multirow[t]{2}{*}{$\begin{array}{l}\text { Enzymatic } \\
\text { activity }\end{array}$} & \multicolumn{2}{|c|}{ Normal condition } & \multicolumn{2}{|c|}{$\begin{array}{l}\text { Pre-incubated (30 min) } \\
\text { with latex (3 } \mu \mathrm{m} \text { diam.) }\end{array}$} \\
\hline & $\begin{array}{l}\text { \% granulo- } \\
\text { cytes }\end{array}$ & $\begin{array}{l}\text { \% hyalino- } \\
\text { cytes }\end{array}$ & $\begin{array}{l}\% \text { granulo- } \\
\text { cytes }\end{array}$ & $\begin{array}{l}\text { \% hyalino- } \\
\text { cytes }\end{array}$ \\
\hline$\beta$-glucuronidase & $2.8 \pm 1.2$ & $3.6 \pm 0.5$ & $9.5 \pm 1.8^{* * *}$ & $5.8 \pm 0.6^{* * *}$ \\
\hline Acid phosphatase & $12.3 \pm 1.0$ & $25.6 \pm 0.6$ & $13.1 \pm 2.1^{\mathrm{ns}}$ & $23.9 \pm 3.2^{\mathrm{ns}}$ \\
\hline
\end{tabular}

$10 \pm 1.7 \%$, phagocytic hyalinocytes $12.7 \pm 1.5 \%$ ). Most haemocytes contain lysosomes inside their cytoplasm, as revealed by Neutral Red accumulation (Fig. 1D). Both granulocytes and hyalinocytes were positive for hydrolytic enzymes (Table 3); $80 \%$ of haemocytes were positive for chloroacetyl esterase (Fig. 1F), $67 \%$ were positive for arylsulphatase and $65 \%$ were positive for non-specific esterase. Acid phosphatase activity occurred in $38 \%$ of cells; the lowest frequency $(6 \%)$ was observed for $\beta$-glucuronidase activity (Fig. 1E). None of the oxidative enzymes assayed were detected in clam haemocytes. Phagocytic activity changed enzyme levels (Table 4). The percentage of cells positive for $\beta$-glucuronidase significantly increased $(p<0.001)$ after the activation of haemocytes by preincubation with foreign particles (latex beads, $3 \mu \mathrm{m}$ diameter).

\section{DISCUSSION}

In accordance with Cheng (1981) and numerous other authors (see the review of Hine 1999), the haemocytes of Chamelea gallina can be grouped into 2 main categories, namely granulocytes (cells containing many granules) and hyalinocytes (with few or no cytoplasmatic granules). Earlier studies on venerid haemocytes indicated the presence of only 1 cell type, the granulocyte (Cuenot 1891, Zack 1955: both cited in Cheng 1981). Nevertheless, the existence of 2 haemocyte types was proposed by Huffman \& Tripp (1982) in Mya arenaria and by Auffret (1985) in Ruditapes philippinarum. In the present work, we determined a percentage of $16.5 \%$ for granulocytes and $79.2 \%$ for hyalinocytes; these data are not in agreement with those of other authors. Renwrantz et al. (1979) found about $70 \%$ granulocytes and $30 \%$ agranulocytes in Crassostrea virginica, confirming a previous study by Galtsoff (1964); these percentages are typical for bivalves (Huffman \& Tripp 1982, Carballal et al. 1997b). In our species, hyalinocytes were more abundant than granulocytes. The cytoplasm of some haemocytes exhibited yellow-orange inclusions larger than granules, most likely lipofuscin-containing phagosomes (Carballal et al. 1997b).

Although most of the haemocytes contained hydrolytic enzymes, only $6 \%$ ingested yeast in vitro. Such low activity was also reported for the mussels Perna perna (Barracco et al. 1999) and Mytilus galloprovincialis (Cajaraville \& Pal 1995) and might be attributable to the lack, in experimental conditions, of humoral opsonins, which 
are otherwise normally present in the haemolymph (Hardy et al. 1977). A higher percentage of phagocytic cells occurs after pre-incubation of latex beads with $\mathrm{CFH}_{\text {; }}$ this suggests the presence of opsonin(s) in the haemolymph, in agreement with the report of Renwrantz and Stahmer (1983) for M. edulis.

The presence of binucleated circulating cells (both granulocytes and hyalinocytes) suggests that differentiated haemocytes may retain the ability to divide, and supports the hypothesis that granulocytes and hyalinocytes represent 2 different cell lines, in agreement with the results reported by Moore \& Lowe (1977) for Mytilus edulis and by Carballal et al. (1997b) for M. galloprovincialis, although hyalinocytes are considered by some authors (Ottaviani et al. 1998) as a young differentiation stage of haemocytes, leading to granulocytes. Moreover, other studies have confirmed various stages of granulocyte differentiation with parallel growth of their specific granules (Cajaraville \& Pal 1995, Carballal et al. 1997b). Chamelea gallina haemocytes display a good adhering ability, unlike the results reported for other venerid species (Foley \& Cheng 1974, Lopez et al. 1997b).

In winter, the haematocrit value was $1.2 \times 10^{6}$; it significantly increased in spring $\left(1.6 \times 10^{6}, \mathrm{p}<0.05\right)$ and summer $\left(2.4 \times 10^{6}, \mathrm{p}<0.001\right)$, but decreased to winter levels in autumn. This variation may reflect the biological characteristics of the individuals, their physiological state and the environmental conditions (Auffret \& Oubella 1995), and may be related to the haemopoietic activity of the bivalves (Anderson 1990, Pipe et al. 1995). The number of haemocytes were influenced by seasonal factors (such as temperature, reproductive cycle, food), as reported by Santarèm et al. (1994) for Mytilus galloprovincialis. Feng (1965) reported that the number of circulating haemocytes in Crassostrea virginica is influenced by the amount of food and the temperature. In our study, the highest value was found in summer, when the highest temperature and abundant food availability occurred in the Adriatic Sea.

In the present work, we also evaluated the presence of various enzyme activities in Chamelea gallina haemocytes by using cytoenzymatic techniques. Both hyalinocytes and granulocytes show positive evidence for certain hydrolytic enzymes inside small granules, which probably correspond to lysosomes (Hayashi 1971). As in other bivalves, not all granules in haemocytes are reactive to lysosomal enzymes (Yoshino \& Cheng 1976, Huffman \& Tripp 1982, Auffret 1989, Pipe 1990).

The highest percentage of positive cells was observed for the 2 esterase types (acetylchloroesterase and non-specific esterase) and for arylsulphatase. It was reported that $95 \%$ of haemocytes were positive for acetylchloroesterase in Mytilus galloprovincialis (Car- ballal et al. 1997a). Non-specific esterase activity was found in Ostrea edulis and Crassostrea gigas haemocytes by Chagot (1989), in Mya arenaria by Huffman \& Tripp (1982), in Tapes philippinarum by Cima et al. (2002), in M. galloprovincialis by Carballal et al. (1997a). Mollusc arylsulphatase has been located in the lysosomes, and less consistently in the Golgi bodies and endoplasmic reticulum, of many different tissues (Pipe \& Moore 1985, Pipe 1987,1990, Cajaraville et al. 1995, Pipe et al. 1997). Unlike esterases, $\beta$-glucuronidase activity was infrequent in Chamelea gallina haemocytes, in agreement with results reported for other bivalves (Bayne et al. 1979, Pipe 1990, Carballal et al. 1997a, Lopez et al. 1997a, Ottaviani et al. 1998). $\beta$-glucuronidase is considered a non-specific humoral defence molecule, owing to the fact that it can hydrolyse acid mucopolysaccharides, which are constituents of bacterial cell walls (Cheng 1976). Acid phosphatase is a typical marker for lysosomes (de Duve 1963), even though extralysosomal localisations of these enzymes have been described in several kinds of cells (Borgers \& Verheyan 1985). Particularly in bivalves, a high activity of acid phosphatase was found in Ruditapes decussatus (Lopez et al. 1997a), M. galloprovincialis (Ottaviani et al. 1998), Mercenaria mercenaria (Yoshino \& Cheng 1976), Mya arenaria (Huffman \& Tripp 1982), Crassostrea virginica (Cheng \& Downs 1988), O. edulis and C. gigas (Auffret 1989), Perna perna (Barracco et al. 1999), M. galloprovincialis (Bayne et al. 1979, Cajaraville et al. 1995, Carballal et al. 1997a), and M. edulis (Moore \& Lowe 1977). Its presence was not reported in T. philippinarum (Cima et al. 2002). $\beta$-glucuronidase activity, but not acid phosphatase activity, increases after cell activation upon the recognition of foreign particles; this indicates a certain degree of regulation of the enzyme activity, in agreement with data obtained under anoxic conditions (Pampanin et al. 2002).

The presence of hydrolytic enzymes (phosphatases, sulphatases, glycosidases) inside cytoplasm granules strongly suggests that they are lysosomes, in agreement with data of Pipe (1990) and Carballal et al. (1997a). This is also confirmed by the neutral red uptake. The cellular uptake of neutral red, a cationic dye accumulated in the lysosomes in a biphasic manner, consists of an initial rapid flowing through the plasma membrane and a subsequent slow accumulation inside lysosomes (Seglen 1983). The amount of neutral red accumulated in cells can give an estimate of the volume of the lysosomal compartment (Pipe et al. 1997).

No oxidative enzymes were detected in Chamelea gallina haemocytes. The absence of phenoloxidase was also reported for Scapharca inaequivalvis (Holden et al. 1994), whereas this enzyme was present in the 
haemocytes of 2 species of Mytilidae: Mytilus edulis (Waite \& Anderse 1980, Coles \& Pipe 1994, Pipe et al. 1997) and M. galloprovincialis; for these species, $100 \%$ haemocytes were positive for peroxidase and $73 \%$ for phenoloxidase (Carballal et al. 1997a). Cima et al. (2002) have demonstrated the presence of peroxidase activity in Tapes philippinarum, a member of the Veneridae family. Further research efforts will be directed towards a better comprehension of the role of haemocytes in C. gallina immunobiology.

Acknowledgements. This research was supported by a grant from the Commission of the European Communities, Agriculture and Fisheries (FAIR) specific RTD programme, CT984465, Evaluation and Improvement of Shellfish Dredge Design and Fishing Effort in Relation to Technical Conservation Measures and Environmental Impact (ECODREDGE). The authors thank Dr. A. Cirelli for technical support.

\section{LITERATURE CITED}

Adema CM, van der Knapp WPW, Sminia T (1991) Molluscan haemocyte-mediated cytotoxicity: the role of reactive oxygen intermediates. Rev Aquat Sci 4:201-223

Anderson DP (1990) Immunological indicators: effects of environmental stress on immune protection and disease outbreaks. In: Adams SA (ed) Biological indicators of stress in fish. Eighth Symposium of the American Fisheries Society, Bethesda, MD

Auffret M (1985) Morphologie comparative des types haemocytaires chez quelques mollusques bivalves d'interet commercial. Thèses doctorale, Universitè de Bretagne Occidentale, Brest

Auffret M (1989) Comparative study of the haemocytes of two oyster species: the European flat oyster, Ostea edulis (Linnaeus) and the Pacific oyster, Crassostrea gigas (Thunberg). J Shellfish Res 8:367-373

Auffret M, Oubella R (1995) Cytological and cytometric analysis of bivalve mollusc haemocytes. In: Stolen JS, Fletcher TC, Smith SA, Zelikoff JT, Kaattari SL, Anderson RS, Soderhall K, Weeks-Perkins BA (eds) Techniques in fish immunology. 4. Immunology and pathology of aquatic invertebrates. SOS Publications, Fair Haven, NJ, p 55-64

Barillari A, Boldrin A, Mozzi C, Rabitti S (1978) Alcune relazioni tra natura dei sedimenti e presenza della vongola Chamelea gallina, nell'Alto Adriatico, presso Venezia. Atti Ist Veneto Sci Lett Arti Cl Sci Fi Mat Nat 137:19-34

Barracco MA, Medeiros ID, Moreira FM (1999) Some haematoimmunological parameters in the mussel Perna perna. Fish Shellfish Immunol 9:387-404

Bayne CJ, Moore MN, Carefoot TH, Thompson RJ (1979) Haemolymph functions in Mytilus californianus. The cytochemistry of haemocytes and their responses to foreign implants and haemolymph factors of phagocytosis. J Invertebr Pathol 34:1-20

Borgers M, Verheyen A (1985) Enzyme cytochemistry. Int Rev Cytol 95:163-227

Burstone MS (1962) Enzyme histochemistry and its application in the study of neoplasms. Academic Press, New York

Cajaraville MP, Pal SG (1995) Morphofunctional study of the haemocytes of the bivalve mollusc Mytilus galloprovincialis with emphasis on endolysosomal compartment. Cell Struct Funct 20:355-367

Cajaraville MP, Pal SG, Robledo Y (1995) Light and electron microscopical localization of lysosomal acid hydrolases in bivalve haemocytes by enzyme cytochemistry. Acta Histochem Cytochem 28:409-416

Cajaraville MP, Olabarrieta I, Marigomez I (1996) In vitro activities in mussel haemocytes as biomarkers of environmental quality: a case of study in the Abra estuary (Biscay Bay). Ecotoxicol Environ Saf 35:253-260

Carballal MJ, Lopez C, Azevedo C, Villalba A (1997a) Enzymes involved in defence function of haemocytes of mussel Mytilus galloprovincialis. J Invertebr Pathol 70:96-105

Carballal MJ, Lopez C, Azevedo C, Villalba A (1997b) Haemolymph cell types of the mussel Mytilus galloprovincialis. Dis Aquat Org 29:127-135

Carballal MJ, Lopez C, Azevedo C, Villalba A (1997c) In vitro study of phagocytic ability of Mytilus galloprovincialis. Lmk. haemocytes. Fish Shellfish Immunol 7:403-416

Chagot D (1989) Caractèrisation morphologique et fonctionelle des hèmocytes d'Ostrea edulis et de Crassostrea gigas, mollusques bivalves. Etudè in vitro de leurs interactions avec le protozoaire Bonaomia ostreae (Ascetospora). Thèse de l'Ecole Pratique des Hautes Etudes, Montpellier

Cheney DC (1971) A summary of invertebrate leucocyte morphology with emphasis on blood elements of the Manila clam, Tapes semidecussatus. Biol Bull 140:353-368

Cheng TC (1976) Beta-glucuronidase in the serum and haemolymph cells of Mercenaria mercenaria and Crassostrea virginica (Mollusca: Pelecypoda). J Invertebr Pathol 27:125-128

Cheng TC (1981) Bivalves. In: Ratcliffe NA, Rowley AF (eds) Invertebrate blood cells. Academic Press, London, p 233-300

Cheng TC (1983) The role of lysosomes in molluscan inflammation. Am Zool 23:129-144

Cheng TC, Cali A (1974) An electron microscope study of the fate of bacteria phagocytized by granulocytes of Crassostrea virginica. Contemp Top Immunobiol 4:25-35

Cheng TC, Dougherty WJ (1989) Ultrastructural evidence for the destruction of Schistosoma mansoni sporocysts associated with elevated lysosomal enzyme levels in Biomphalaria glabrata. J Parasitol 75:928-941

Cheng TC, Downs CU (1988) Intracellular acid phosphatase and lysozyme levels in subpopulations of oysters, Crassostrea virginica, haemocytes. J Invertebr Pathol 52: 163-167

Cheng TC, Rodrick GE (1975) Lysozymes and other enzymes in the haemolymph of Crassostrea virginica and Mercenaria mercenaria. Comp Biochem Physiol B 52:443-447

Cima F, Matozzo V, Marin MG, Ballarin L (2002) The haemocytes of the clam Tapes philippinarum: a morpho-functional characterisation. Fish Shellfish Immunol (in press)

Coles JA, Pipe RK (1994) Phenoloxidase activity in the haemolymph and haemocytes of the marine mussel MytiIus edulis. Fish Shellfish Immunol 4:337-352

de Duve C (1963) The lysosome concept. In: de Reuck AV, Cameron M (eds) Lysosomes, Ciba Foundation Symposium. Little, Brown \& Company, Boston, MA, p 1-35

del Piero D (1998) Indagini sullo stock di Chamelea gallina (L. 1758), vongola comune nei compartimenti di Monfalcone (1984-1997) e Venezia (1990-1997). Biol Mar Mediterr 5: 395-399

Feng SY (1965) Heart rate and leucocyte circulation in Crassostrea virginica (Gmelin). Biol Bull 128:198-210

Foley DA, Cheng TC (1974) Morphology, haematology parameters and behaviour of haemolymph cells of the quahaug clam, Mercenaria mercenaria. Biol Bull 146:343-356

Froglia C (1975) Osservazioni sull'accrescimento di 'Chamelea gallina' (L.) ed 'Ensis minor' (Chenu) nel Medio Adri- 
atico. Quad Lab Tecnol Pesca 2:37-48

Froglia C (1989) Clam fisheries with hydraulic dredge in the Adriatic Sea. In: Caddy JF (ed) Marine invertebrate. John Wiley \& Sons Inc, New York, p 507-524

Galstoff PS (1964) The American oyster Crassostrea virginica Gmelin. Fish Bull US Fish Wildl Serv 64:1-480

Goldfisher S (1965) The cytochemical demonstration of lysosomal aryl sulphatase activity by light and electron microscopy. J Histochem Cytochem 13:520-523

Gomori G (1948) Histochemical demonstration of sites of choline esterase activity. Proc Soc Exp Biol Med 68:354-358

Graham RC, Karnovsky MJ (1966) The early stage of adsorption of injected horseradish peroxidase in the proximal tubules of mouse kidney: ultrastructural cytochemistry by a new technique. J Histochem Cytochem 14:291-302

Hardy SW, Fletcher TC, Olafsen JA (1977) Aspects of cellular and humoral defence mechanisms in the Pacific oyster, Crassostrea gigas. In Solomon JB, Horton JD (eds) Developmental immunobiology. Elsevier North Holland Biomedical Press, Amsterdam, p 59-66

Hayashi M (1971) Demonstration of acid phosphatase activity using 1-acetyl-3-indolyl phosphate as substrate. J Histochem Cytochem 19:175-185

Hayashi M, Nakajima Y, Fishman WH (1964) The cytologic demonstration of $\beta$-glucuronidase employing naphtol ASBI glucuronide and hexazonium pararosanilin; a preliminary report. J Histochem Cytochem 12:293-297

Hine PM (1999) The inter-relationships of bivalve haemocytes. Fish Shellfish Immunol 9:367-385

Holden JA, Pipe RK, Quaglia A, Ciani G (1994) Blood cells of the arcid clam Scarpharca inaequivalvis. J Mar Biol Assoc UK 74:287-299

Hose JE, Martin GG, Nguyen VA, Lucas J, Rosenstein AT (1987) Cytochemical features of shrimp haemocytes. Biol Bull 173:178-187

Huffman JE, Tripp MR (1982) Cell types and hydrolytic enzymes of soft shell clam (Mya arenaria) haemocytes. J Invertebr Pathol 40:68-74

Lojda Z (1977) Studies on glycyl-proline naphthylamidase. I. Lymphocytes. Histochemistry 54:299-309

Lojda Z, Gossrau R, Schibler TH (1979) Enzyme histochemistry: a laboratory manual. Springer-Verlag, Berlin

Lopez C, Carballal MJ, Azevedo C, Villalba A (1997a) Enzyme characterisation of the circulating haemocytes of the carpet shell clam, Ruditapes decussatus (Mollusca: bivalvia). Fish Shellfish Immunol 7:595-608

Lopez C, Carballal MJ, Azevedo C, Villalba A (1997b) Morpholgical characterization of the haemocytes of the clam, Ruditapes decussatus (Mollusca: Bivalvia). J Invertebr Pathol 69:51-57

Mohandas A, Cheng TC, Cheng JB (1985) Mechanism of lysosomal enzymes release from Mercenaria mercenaria granulocytes: a scanning electron microscope study. J Invertebr Pathol 46:189-197

Moloney WC, McPherson K, Fliegelman L (1960) Esterase activity in leukocytes and demonstrated by the use of naphtol AS-D chloroacetate substrate. J Histochem Cytochem 8:200-207

Moore CA, Eble AF (1977) Cytochemical aspects of Mercenaria mercenaria haemocytes. Biol Bull 152:105-119

Moore CA, Lowe DM (1977) The cytology and cytochemistry of the haemocytes of Mytilus edulis and their responses to

Editorial responsibility: Albert Sparks,

Seattle, Washington, USA experimentally injected carbon particles. J Invertebr Pathol 29:18-30

Ottaviani E, Franchini A, Barbieri D, Kletsas D (1998) Comparative and morphofunctional studies on Mytilus galloprovincialis haemocytes: presence of two aging-related haemocytes stages. Ital J Zool 65:349-354

Pampanin DM, Ballarin L, Carotenuto L, Marin MG (2002) Air exposure and functionality of Chamelea gallina haemocytes: effects on haematocrit, adhesion, phagocytosis and enzyme contents. Comp Biochem Physiol A 131(3): 605-614

Pipe RK (1987) Ultrastructural and cytochemical study on interactions between nutrient storage cells and gametogenesis in the mussel Mytilus edulis. Mar Biol 96:519-528

Pipe RK (1990) Hydrolytic enzymes associated with the granular haemocytes of the marine mussel Mytilus edulis. Histochem J 22:595-603

Pipe RK, Moore MN (1985) The ultrastructural localization of lysosomal acid hydrolases in developing oocytes of the common marine mussel Mytilus edulis. Histochem J 17: 939-949

Pipe RK, Coles JA, Thomas ME, Fossato VU, Pulsford AL (1995) Evidence for environmentally derived immunomodulation in mussels from the Venice Lagoon. Aquat Toxicol 32:59-73

Pipe RK, Farley SR, Coles JA (1997) The separation and characterisation of haemocytes from the mussel Mytilus edulis. Cell Tissue Res 289:537-545

Renwrantz L, Stahmer A (1983) Opsonizing properties of an isolated haemolymph agglutinin and demonstration of lectin-like recognition molecules at the surface of haemocytes from Mytilus edulis. J Comp Physiol 146:535-546

Renwrantz L, Yoshino T, Cheng TC, Auld K (1979) Size determination of haemocytes from the American oyster, Crassostrea virginica, and the description of a phagocytosis mechanism. Zool Jb Physiol 83:1-12

Rodrick GE, Ulrich SA (1984) Microscopial studies on the haemocytes of bivalves and their phagocytic interaction with selected bacteria. Helgol Meeresunters 37:167-176

Santarèm MM, Robledo JAF, Figueras A (1994) Seasonal changes in haemocytes and serum defence factors in the blue mussel Mytilus galloprovincialis. Dis Aquat Org 18: $217-222$

Seglen PO (1983) Inhibitors of lysosomal function. In Brehèlin $\mathrm{M}$ (ed) Immunity in invertebrates. Springer-Verlag, Berlin, p 112-124

Vetvicka V, Sima P (1998) Evolutionary mechanisms of defences reactions. Birkhauser Verlag, Basel

Wachstein M, Meisel E (1957) Histochemistry of hepatic phosphatases at a physiological $\mathrm{pH}$ with special reference to the demonstration of bile canaliculi. Am J Clin Pathol 27: $12-23$

Waite JH, Anderse SO (1980) 3-4, dihydroxyphenylalanine (DOPA) and sclerotization of periostracum in Mytilus edulis. Biol Bull 158:164-173

Yoshino TP (1988) Phospholipase C-like activity in phagocytic cells of the Asian clam, Corbicula fluminea, and its possible role in cell-mediated cytolytic reactions. J Invertebr Pathol 51:32-40

Yoshino TP, Cheng TC (1976) Fine structural localization of acid phosphatase in granulocytes of the pelecypod Mercenaria mercenaria. Trans Am Microsc Soc 95:215-220

Submitted: May 31, 2000; Accepted: November 23, 2001

Proofs received from author(s): May 21, 2002 